\title{
EFFECT OF HYPOPHYSECTOMY ON IMPLANTATION IN THE MOUSE
}

\author{
B. M. BINDON* AND D. R. LAMOND ${ }^{*}$ \\ C.S.I.R.O. Division of Animal Physiology, Cunningham Laboratory, St. Lucia, \\ Queensland, Australia
}

(Received 6th February 1968)

\begin{abstract}
Summary. Experiments were conducted in pregnant mice in an attempt to clarify the role of the pituitary gland in implantation in this species. Hypophysectomy was performed at various times during Days 2 to 5 of pregnancy and replacement studies with human chorionic gonadotrophin (HCG) or progesterone were carried out.

Results indicated that pituitary involvement in the initiation of implantation was confined to the early part of Day 3. Changes in the photoperiod altered the time of pituitary involvement, thus exposing a possible source of error in between-laboratory comparisons in this type of study.

Pregnancy was maintained in hypophysectomized mice by daily injection with HCG. The minimum daily dose was between $1 \cdot 1$ and 3.3 i.u. Embryos maintained by HGG were smaller than those in hypophysectomized mice injected with progesterone.
\end{abstract}

\section{INTRODUGTION}

The ovarian steroid requirements for ovum implantation in the rat are now comparatively well defined. Studies including ovariectomy (Chambon, 1949; Canivenc \& Laffargue, 1956; Cochrane \& Meyer, 1957) or hypophysectomy (Cochrane \& Meyer, 1957; Alloiteau, 1961) before implantation, showed that daily replacement with progesterone allowed viable blastocysts to remain in a dormant state in the uterine lumen. Implantation of these blastocysts required the addition of a small amount of oestrogen. It is generally believed that ovum implantation occurs after a discretely timed sequence of progesterone and oestrogen secretion from the ovary (Shelesnyak, Kraicer \& Zeilmaker, 1963; Yasukawa \& Meyer, 1966; reviews by Shelesnyak, 1960; Mayer, 1963; Psychoyos, 1966). The timing of the so-called oestrogen 'surge' appears to be confined to a few hours late on Day 3 of pregnancy (Zeilmaker, 1963).

The role of the pituitary in regulating these ovarian steroid changes is not well defined. Little is known of the type or the amounts of pituitary gonadotrophins involved in the postulated ovarian steroid changes before implantation. In addition, some disagreement exists as to the exact timing of pituitary involvement, especially in relation to the postulated surge of oestrogen. Thus, one

* Present address: Department of Veterinary Physiology, University of Sydney, Sydney, Australia. 
group of workers has defined a neurally-controlled release of gonadotrophin by the pituitary early on Day 3 as the key event in the initiation of implantation (Alloiteau, 1961 ; Psychoyos, 1963). In another laboratory (Zeilmaker, 1963), the critical period of pituitary involvement was some $10 \mathrm{hr}$ later on Day 3 and this event was apparently not under neural control.

Comparatively little work of this nature has been carried out in the mouse. For this reason, and in the hope of clarifying certain aspects of pituitary function during implantation in the mouse, hypophysectomy was performed at various times after coitus and the effect of progesterone and HCG on implantation examined.

\section{MATERIALS AND METHODS}

\section{Animals}

Randomly bred nulliparous albino mice of the Sydney White strain, aged 8 to 10 weeks and weighing 23 to $27 \mathrm{~g}$, were joined in groups of three with one male. The animals were kept under uniform environmental conditions (Bindon $\&$ Lamond, 1966a), with the temperature kept constant at $22.5 \pm 1.5^{\circ} \mathrm{C}$, humidity at 55 to $60 \%$, and lights on from 06.00 to 18.00 hours. The mice were allotted at random to treatment groups after detection of the vaginal plug (i.e. Day 0 of pregnancy).

\section{Hypophysectomy}

The technique employed was similar to that described by Lamond \& Emmens (1959) for immature mice. Sham hypophysectomy included all stages of the operation except extirpation of the pituitary. Mice were provided with $10 \%$ glucose in the drinking water following surgery and were maintained (five/group) in an environment of approximately $27^{\circ} \mathrm{C}$ in mouse cages measuring $8 \times 12 \times 4 \mathrm{in}$. Completeness of hypophysectomy was verified by examination of the pituitary fossa under a binocular microscope. Mice with pituitary remnants were eliminated from the experiments.

\section{Hormones}

Human chorionic gonadotrophin (Pregnyl, Organon Ltd, London); progesterone (B.P.) were used.

\section{Collection of data}

On Day 8, records were taken of each animal's body weight, the number of viable and non-viable embryos (assessed from a set of standards kept for comparison) and the wet weight of the uterus.

An estimate of 'implant' weight (i.e. the weight of the implanted embryo plus its associated segment of deciduomatous tissue) for each mouse was made as follows:

Mean implant weight $(\mathrm{mg})=$

Weight pregnant uterus - Weight non-pregnant uterus

Number of implanted embryos 
The weights of non-pregnant uteri used in this formula were $70 \mathrm{mg}$ and 36 $\mathrm{mg}$ for intact and hypophysectomized mice respectively.

\section{RESULTS}

Effect of HCG on implantation in mice hypophysectomized at various stages of early pregnancy (Experiment 1)

Mice were hypophysectomized either between 10.00 and 10.30 hours or between 16.00 and 16.30 hours on Days 2, 3, 4 or 5 of pregnancy and injected next day at either 10.00 or 16.00 hours with $1 \cdot 1,3 \cdot 3$, or 10.0 i.u. HCG. Injections continued each day at the same time until Day 8 when the mice were killed. The

TABLE 1

SUMMARY OF ANALYSIS OF VARIANCE FOR EXPERIMENT 1

\begin{tabular}{|c|c|c|}
\hline Source of variation & d.f. & Mean square \\
\hline $\begin{array}{l}\text { Day of hypophysectomy (D) } \\
\text { linear DL } \\
\text { quadratic DQ } \\
\text { cubic DG }\end{array}$ & $\begin{array}{l}1 \\
1 \\
1\end{array}$ & $\begin{array}{l}3664 * * * \\
1282 * * * \\
228\end{array}$ \\
\hline $\begin{array}{l}\text { Time of hypophysectomy }(\mathrm{T}) \\
10.00 \text { hours versus } 16.00 \text { hours }\end{array}$ & 1 & $2994 * * *$ \\
\hline $\begin{array}{l}\text { Time of injection on day after } \\
\text { hypophysectomy }(\mathrm{I}) 10.00 \\
\text { hours versus } 16.00 \text { hours }\end{array}$ & 1 & $313^{*}$ \\
\hline $\begin{array}{l}\text { Dose of HCG }(G) \\
\text { linear GL } \\
\text { quadratic GQ }\end{array}$ & $\begin{array}{l}1 \\
1\end{array}$ & $\begin{array}{l}6772 * * * \\
2967 * * *\end{array}$ \\
\hline $\begin{array}{l}\text { Interactions } \\
\mathrm{DL} \times \mathrm{I} \\
\mathrm{DL} \times \mathrm{GL} \\
\mathrm{DQ} \times \mathrm{GQ} \\
\mathrm{DC} \times \mathrm{T}\end{array}$ & $\begin{array}{l}1 \\
1 \\
1 \\
1\end{array}$ & $\begin{array}{l}628 * * \\
744 * * \\
563 * * \\
649 * *\end{array}$ \\
\hline Remainder & 36 & 85 \\
\hline Error & $\infty$ & $82 \cdot 1$ \\
\hline
\end{tabular}

$* 0.01<P<0.05 ; * * 0.001<P<0.01 ; * * * P<0.001$.

The number of mice in which implantation occurred was transformed to angles $(n=10)$ for each of the forty-eight treatment groups.

design was thus $4 \times 2 \times 2 \times 3$ factorial, with eleven or twelve pregnant mice per treatment. The forty-eight treatment groups were filled in random order during a period of 3 weeks. There was no evidence of variation in the results due to this period of time.

Additional groups of ten mice were subjected to sham hypophysectomy at 10.00 to 10.30 hours or 16.00 to 16.30 hours on Days 2, 3, 4 or 5 of pregnancy and were killed on Day 8 . These were not given HCG.

The percentage of mice showing implantation (i.e. viable or non-viable embryos present on Day 8) for each of the forty-eight treatment groups is shown 
in Text-fig. 1 with summary of the analysis of variance in Table 1. These results show that:

(i) The number of mice pregnant after hypophysectomy on Day 2 was significantly lower than after hypophysectomy on Days 3, 4 or 5 .

(ii) The overall number of mice pregnant after hypophysectomy at 10.00 hours was significantly lower than after hypophysectomy at 16.00 hours. This was due to differences on Days 2 and 3 but not Days 4 and 5 (interaction term $\mathrm{DC} \times \mathrm{T})$.

(iii) Injections of HCG at 10.00 hours were followed by greater numbers of implantations than injections at 16.00 hours, especially on Days 4 and 5 (interaction term $\mathrm{DL} \times \mathrm{I}$ ).

(iv) The effect of HCG injections clearly depended on the dose administered. It can be seen from the analysis and Text-fig. 1 that $1 \cdot 1$ i.u. HGG was unable

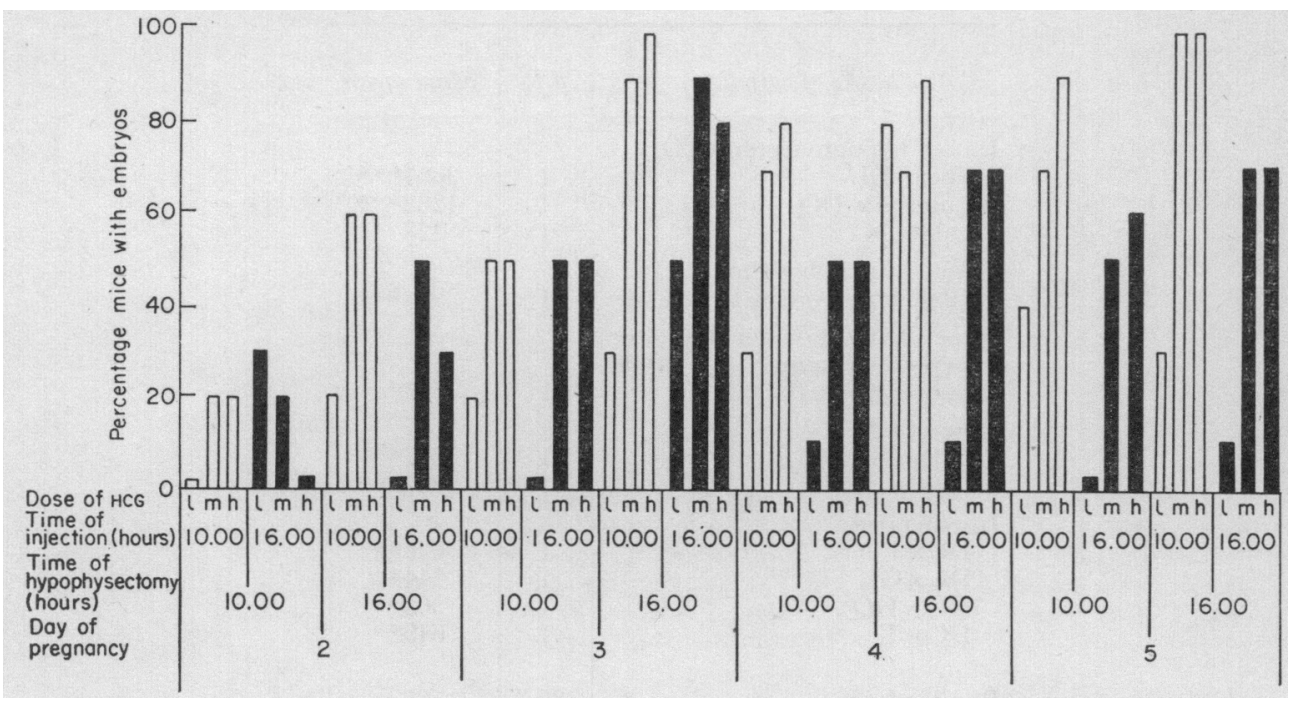

Texr-FIG. 1. The percentage of mice with implanted embryos on Day 8 following hypophysectomy and HCG administration. Groups receiving HCG $(1=1 \cdot 1$ i.u.; $m=3 \cdot 3$ i.u.; $\mathrm{h}=10.0 \mathrm{i}$.u.) at 10.00 hours or 16.00 hours are shown by either open or closed columns, respectively. There were ten mice per group.

consistently to maintain pregnancy whereas $3 \cdot 3$ i.u. was successful. There was no significant difference between 3.3 i.u. and $10 \cdot 0$ i.u. HGG. The difference between $1 \cdot 1$ i.u. and the other two doses of HCG was most marked on Days 4 and 5.

(v) Where implantation occurred, more than $75 \%$ of mice had seven to ten embryos which is considered normal for mice in this colony.

The body weights, numbers of embryos and implant weights are shown in Table 2. Sham hypophysectomy had no marked effect on body weights, proportions pregnant or numbers of implantations. Mean implant weight was reduced in the groups subjected to sham hypophysectomy at 10.00 hours on Days 4 and 5.

Implant weights in hypophysectomized pregnant mice were much lower than those of either sham-hypophysectomized or controls (i.e. 18 to $20 \mathrm{mg}$ for 
hypophysectomized mice compared with 28 to $30 \mathrm{mg}$ for shams and controls). The correlations between body weight and embryo weight within the hypophysectomized, sham or control groups were not significant (Table 2).

Effect of hypophysectomy on Days 2 and 3 of pregnancy on implantation in mice given progesterone (Experiment 2)

The technique employed by Alloiteau (1961) was used to study the timing of pituitary involvement in the initiation of implantation. If progesterone is

TABLE 2

COMPARISON OF EFFECTS OF HYPOPHYSEGTOMY AND SHAM HYPOPHYSEGTOMY ON BODY WEIGHTS AND IMPLANT WEIGHTS OF MICE ON DAY 8 OF PREGNANCY

\begin{tabular}{|c|c|c|c|c|c|}
\hline Day and time of operation & $\begin{array}{c}\text { Mean body } \\
\text { weight } \\
(g \pm S . E .)\end{array}$ & $\begin{array}{l}\text { Proportion } \\
\text { pregnant* }\end{array}$ & $\begin{array}{c}\text { Mean no. of } \\
\text { embryos } \\
( \pm S . E .)\end{array}$ & $\begin{array}{c}\text { Mean } \dagger \\
\text { implant } \\
\text { weight } \\
(m g \pm S . E .)\end{array}$ & $\begin{array}{l}\text { Correlation between } \\
\text { body weight and } \\
\text { implant weight }\end{array}$ \\
\hline $\begin{array}{r}\text { Sham hypophysectomy } \\
\text { Day 2, } 10.00 \text { hours } \\
16.00 \text { hours } \\
\text { Day } 3,10.00 \text { hours } \\
16.00 \text { hours } \\
\text { Day } 4,10.00 \text { hours } \\
16.00 \text { hours } \\
\text { Day } 5,10.00 \text { hours } \\
16.00 \text { hours } \\
\end{array}$ & $\begin{array}{l}26 \cdot 6 \pm 0 \cdot 8 \\
25 \cdot 9 \pm 3 \cdot 8 \\
25 \cdot 3 \pm 2 \cdot 3 \\
25 \cdot 9 \pm 1 \cdot 7 \\
24 \cdot 0 \pm 0 \cdot 5 \\
25 \cdot 2 \pm 0 \cdot 5 \\
24 \cdot 4 \pm 0 \cdot 4 \\
25 \cdot 3 \pm 0 \cdot 5\end{array}$ & $\begin{array}{l}7 / 10(0) \\
8 / 10(0) \\
9 / 10(0) \\
9 / 10(0) \\
8 / 10(0) \\
8 / 10(0) \\
8 / 10(0) \\
10 / 10(0)\end{array}$ & $\begin{array}{l}9 \cdot 7 \pm 0.5 \\
8 \cdot 0 \pm 1 \cdot 2 \\
8 \cdot 5 \pm 0.4 \\
6 \cdot 6 \pm 0.8 \\
8 \cdot 4 \pm 0.3 \\
8 \cdot 5 \pm 0 \cdot 2 \\
7 \cdot 0 \pm 0.7 \\
7 \cdot 8 \pm 0.8\end{array}$ & $\begin{array}{l}27 \cdot 7 \pm 0 \cdot 3 \\
25 \cdot 7 \pm 3 \cdot 1 \\
31 \cdot 8 \pm 1 \cdot 5 \\
25 \cdot 8 \pm 1 \cdot 2 \\
20 \cdot 9 \pm 1 \cdot 4 \\
30 \cdot 3 \pm 2 \cdot 1 \\
17 \cdot 4 \pm 1 \cdot 1 \\
28 \cdot 5 \pm 0 \cdot 8\end{array}$ & $\begin{array}{l}+0.11 \\
+0.001 \\
-0.4 \\
+0.09 \\
+0.13 \\
+0.04 \\
+0.2 \\
+0.24\end{array}$ \\
\hline $\begin{array}{c}\text { Hypophysectomy (pooled gre } \\
\text { Day } 2,10.00 \text { hours } \\
16.00 \text { hours } \\
\text { Day } 3,10.00 \text { hours } \\
16.00 \text { hours } \\
\text { Day } 4,10.00 \text { hours } \\
16.00 \text { hours } \\
\text { Day } 5,10.00 \text { hours } \\
16.00 \text { hours }\end{array}$ & $\begin{array}{l}\text { ps) } \\
21 \cdot 4 \pm 0.3 \\
20.9 \pm 0 \cdot 3 \\
21 \cdot 1 \pm 0.2 \\
21 \cdot 4 \pm 0.3 \\
21 \cdot 4 \pm 0.2 \\
21.9 \pm 0.2 \\
22 \cdot 1 \pm 0.3 \\
21.9 \pm 0.3\end{array}$ & $\begin{array}{l}9 / 60(3) \\
22 / 60(7) \\
22 / 60(6) \\
44 / 60(7) \\
29 / 60(6) \\
39 / 60(3) \\
31 / 60(18) \\
38 / 60(13)\end{array}$ & $\begin{array}{l}7 \cdot 6 \pm 0.6 \\
7 \cdot 8 \pm 0.5 \\
5 \cdot 1 \pm 0.6 \\
8 \cdot 2 \pm 0.2 \\
7 \cdot 9 \pm 0.5 \\
8 \cdot 9 \pm 0.7 \\
7 \cdot 2 \pm 0.5 \\
7 \cdot 8 \pm 0.4\end{array}$ & $\begin{array}{l}18 \cdot 2 \pm 3 \cdot 1 \\
12 \cdot 9 \pm 1 \cdot 6 \\
13 \cdot 6 \pm 1 \cdot 1 \\
18 \cdot 5 \pm 1 \cdot 0 \\
17 \cdot 9 \pm 1.6 \\
19.9 \pm 0.9 \\
12.4 \pm 1 \cdot 3 \\
14 \cdot 1 \pm 0.44\end{array}$ & $\begin{array}{l}-0.03 \\
+0.02 \\
+0.07 \\
+0.05 \\
+0.05 \\
+0.05 \\
+0.04 \\
+0.2\end{array}$ \\
\hline No treatment & $26 \cdot 7 \pm 0.8$ & $10 / 12(0)$ & $7 \cdot 5 \pm 0.8$ & $29 \cdot 6 \pm 2 \cdot 5$ & -0.06 \\
\hline
\end{tabular}

* Numbers in parentheses refer to the animals in which pregnancy was terminating at slaughter.

$\dagger$ Mean implant weight $=\frac{\text { Weight of pregnant uterus }- \text { Weight non-pregnant uterus }}{\text { No. of embryos }}$.

injected regularly from the time of hypophysectomy, implantation will not occur in the absence of oestrogen. Thus hypophysectomy before endogenous secretion of oestrogen prevents implantation under these conditions, whereas hypophysectomy after the so-called oestrogen surge will not prevent implantation. Results of Experiment 1 indicated that this occurred on the evening of Day 2 or the morning of Day 3.

Groups of ten to twelve pregnant mice, aged 8 to 10 weeks, were hypophysectomized at 16.00 or 23.00 hours on Day 2. Immediately after hypophysectomy and thereafter, at that time, until Day 8, half of each group was injected subcutaneously with $10 \mu \mathrm{g}$ and half with $1 \mathrm{mg}$ of progesterone in 0.1 $\mathrm{ml}$ oil. The number of mice with embryos was recorded at slaughter on Day 8. 
There was no evidence of implantation in any of the groups which received 10 $\mu \mathrm{g}$ progesterone/day (Table 3 ). In the remainder, none of those hypophysectomized at 16.00 or 23.00 hours on Day 2 had implanted embryos, while thirtynine out of forty of those hypophysectomized at 07.00 hours or later on Day 3 had normal numbers of implantation sites. Implant weights (15 to $18 \mathrm{mg}$ ) for those mice hypophysectomized before 12.00 hours on Day 3 were similar to those of the hypophysectomized mice of Exp. 1. In the groups hypophysectomized later on Day 3, implant weights were similar to those of untreated, intact mice (20 to $26 \mathrm{mg}$ ).

Comparison of the times at which hypophysectomy prevented implantation in mice from two light regimes (Experiment 3 )

The aim of this experiment was to study the relation between the photoperiod and the time of pituitary involvement in initiating implantation.

Mice were born and reared in two breeding rooms of similar size and structure (but not adjacent) and with similar conditions of temperature and humidity.

TABLE 3

EFFECT OF TIME OF HYPOPHYSECTOMY ON IMPLANTATION IN MICE TREATED WITH 1 MG OF PROGESTERONE (EXP. 2)

\begin{tabular}{|c|c|c|c|}
\hline $\begin{array}{c}\text { Day and time of } \\
\text { hypophysectomy }\end{array}$ & $\begin{array}{c}\text { Proportion with } \\
\text { implanted } \\
\text { embryos on } \\
\text { Day } 8\end{array}$ & $\begin{array}{l}\text { Mean }( \pm S . E .) \\
\text { No. embryos/ } \\
\text { mouse }\end{array}$ & $\begin{array}{c}\text { Mean implant } \\
\text { weight } \\
(m g \pm S . E .)\end{array}$ \\
\hline $\begin{array}{ll}\text { Day } 2 & 16.00 \text { hours } \\
\text { Day } 2 & 23.00 \text { hours } \\
\text { Day } 3 & 07.00 \text { hours } \\
\text { Day } 3 & 10.00 \text { hours } \\
\text { Day } 3 & 12.00 \text { hours } \\
\text { Day } 3 & 14.00 \text { hours } \\
\text { Day } 3 & 16.00 \text { hours } \\
\text { Day } 3 & 18.00 \text { hours } \\
\text { Day } 3 & 22.00 \text { hours }\end{array}$ & $\begin{array}{l}0 / 5 \\
0 / 6 \\
5 / 5 \\
5 / 5 \\
6 / 7 \\
5 / 5 \\
6 / 6 \\
6 / 6 \\
6 / 6\end{array}$ & $\begin{array}{c}\text { 二 } \\
7.4 \pm 0.7 \\
8 \cdot 8 \pm 0.3 \\
6 \cdot 3 \pm 1.4 \\
9 \cdot 4 \pm 0.2 \\
8 \cdot 3 \pm 0.4 \\
7 \cdot 6 \pm 0.8 \\
8 \cdot 0 \pm 0.8\end{array}$ & $\begin{array}{c}\text { 二 } \\
14 \cdot 8 \pm 0 \cdot 7 \\
18 \cdot 4 \pm 1 \cdot 9 \\
16 \cdot 1 \pm 1 \cdot 4 \\
26 \cdot 0 \pm 4 \cdot 2 \\
21 \cdot 3 \pm 1 \cdot 6 \\
17 \cdot 7 \pm 3 \cdot 2 \\
26 \cdot 7 \pm 4 \cdot 8\end{array}$ \\
\hline
\end{tabular}

In Room I the lights were on from 06.00 to 18.00 hours and in Room III they were on from 07.00 until 17.00 hours. Groups of six to twelve mice from each room and of the same age ( 8 to 10 weeks) and body weight were hypophysectomized at 24.00 hours on Day 2 or at $01.00,02.00,03.00,04.00,06.00$ or 09.00 hours on Day 3. All mice were injected with $1 \mathrm{mg}$ of progesterone immediately after hypophysectomy and then each day at 09.00 hours until they were killed on Day 8, when the number of mice with embryos was recorded.

The results are presented in Table 4. Implantation was prevented in mice from both rooms by hypophysectomy at 24.00 hours on Day 2, thus confirming the results of Exp. 2. Hypophysectomy of mice in Room I between 01.00 and 04.00 hours prevented implantation in only sixteen of the thirty-seven mice treated. However, a high proportion of mice (twenty-seven of thirty-one) in Room III failed to implant when hypophysectomy was performed between 01.00 and 04.00 hours. By 06.00 hours, hypophysectomy did not prevent implantation in mice from either light regime. 


\section{DISCUSSION}

It was shown in Exp. 1 that hypophysectomy at 16.00 hours on Day 3 or later did not prevent implantation in mice treated with adequate amounts of HCG. The results of Exp. 2, in which the timing of pituitary involvement was more closely examined along the lines of Alloiteau (1961), indicate that (in the presence of adequate progesterone) the role of the pituitary in initiating implantation is completed by 07.00 hours on Day 3. Considered in relation to current theory of the hormonal control of rodent implantation, these results suggest that the pituitary stimulus for ovarian oestrogen production occurs between 24.00 hours on Day 2 and 07.00 hours on Day 3. This substantiates the time relations reported by Alloiteau (1961) but is at variance with the results of Zeilmaker (1963) for the progesterone-treated rat.

TABLE 4

THE INFLUENCE OF HYPOPHYSECTOMY ON IMPLANTATION IN MICE FROM TWO LIGHT REGIMES (EXP. 3)

\begin{tabular}{|c|c|c|c|c|c|c|}
\hline \multirow{2}{*}{$\begin{array}{l}\text { Time of hypophysectomy } \\
\text { during pregnancy }\end{array}$} & \multicolumn{3}{|c|}{$\begin{array}{l}\text { Room I } \\
\text { (lights on } 06.00 \text { to } 18.00 \text { hours) }\end{array}$} & \multicolumn{3}{|c|}{$\begin{array}{l}\text { Room III } \\
\text { (lights on } 07.00 \text { to } 17.00 \text { hours })\end{array}$} \\
\hline & $\begin{array}{l}\text { No. of } \\
\text { mice }\end{array}$ & $\begin{array}{l}\text { Proportion with } \\
\text { implanted embryos }\end{array}$ & $\begin{array}{c}\text { Mean } \\
( \pm S . E .)^{*} \text { No. } \\
\begin{array}{c}\text { of embryosi } \\
\text { mouse }\end{array}\end{array}$ & $\begin{array}{l}\text { No. of } \\
\text { mice }\end{array}$ & $\begin{array}{c}\text { Proportion with } \\
\text { implanted embryos }\end{array}$ & $\frac{\text { Mean }}{( \pm S . E .)^{-N o} \text { No. }}$ \\
\hline $\begin{array}{l}\text { Day } 2,24.00 \text { hours } \\
\text { Day } 3,01.00 \text { hours } \\
\text { Day } 3,02.00 \text { hours } \\
\text { Day } 3,03.00 \text { hours } \\
\text { Day } 3,04.00 \text { hours } \\
\text { Day } 3,06.00 \text { hours } \\
\text { Day } 3,09.00 \text { hours }\end{array}$ & $\begin{array}{r}7 \\
12 \\
12 \\
6 \\
7 \\
7 \\
8\end{array}$ & $\begin{array}{l}0 / 7 \\
4 / 12 \\
7 / 12 \\
4 / 6 \\
6 / 7 \\
7 / 7 \\
8 / 8\end{array}$ & $\begin{array}{l}-\overline{ } \\
2 \cdot 2 \pm 0 \cdot 8 \\
5 \cdot 1 \pm 0 \cdot 7 \\
4 \cdot 0 \pm 0 \cdot 8 \\
5 \cdot 8 \pm 1 \cdot 0 \\
7 \cdot 1 \pm 0 \cdot 6 \\
7 \cdot 4 \pm 0 \cdot 5\end{array}$ & $\begin{array}{r}8 \\
8 \\
10 \\
7 \\
6 \\
8 \\
11\end{array}$ & $\begin{array}{c}0 / 8 \\
0 / 8 \\
2 / 10 \\
1 / 7 \\
1 / 6 \\
8 / 8 \\
11 / 11\end{array}$ & $\begin{array}{c}\overline{-} \\
2 \cdot 5 \pm 0 \cdot 5 \\
5 \\
10 \\
5 \cdot 8 \pm 0 \cdot 9 \\
7 \cdot 4 \pm 0 \cdot 4\end{array}$ \\
\hline
\end{tabular}

* i.e. of those mice with embryos.

An interesting difference therefore exists with regard to the timing of pituitary involvement in these two reports. This difference may be related to the fact that the photoperiod differed in the two colonies $(10 \mathrm{hr}: 14 \mathrm{hr}$, light:dark in the case of Alloiteau and $14 \mathrm{hr}: 10 \mathrm{hr}$, light:dark in the case of Zeilmaker). This possibility has the support of an earlier report (Bindon \& Lamond, 1966b) on the relation between the lighting schedule and time of pituitary gonadotrophin release in immature mice from this colony. The results of Exp. 3 demonstrate that small differences in lighting may impose a confounding variable in comparisons between laboratories in this type of work.

There was a significant dose-response relationship between HCG and the number of mice with implanted embryos. The sensitivity of the implantation response to HCG (e.g. as shown by the groups hypophysectomized at 16.00 hours on Day 4 and injected at 10.00 hours next day) suggests a useful and meaningful assay for luteotrophin. It is apparent that the daily requirement for maintenance of early pregnancy lies within the range 1.1 to $3.3 \mathrm{i}$.u. HCG. This may be compared with a daily requirement of 0.25 to 1.0 i.u. HGG for the rat after 
hypophysectomy on Day 6 (Alloiteau \& Bouhours, 1965). Zeilmaker (1963) maintained pregnancy in the rat after hypophysectomy on the afternoon of Day 3 by twice-daily injections of $25 \mathrm{i}$.u. of ovine lactogenic hormone.

Embryos from hypophysectomized mice were smaller on average than embryos from either intact or sham-operated mice. Body weights of hypophysectomized mice were considerably lower than the controls but the correlation between body weight and implant weight was not significant. Progesterone (Exp. 2) and pregnant mare serum gonadotrophin (unpublished) maintained normal embryo size even though body weights were reduced. Perhaps the reason HCG did not stimulate adequate hormone production from the ovaries was that injections were not given often enough. HGG has a shorter half-life in body fluids than PMSG (Zondek \& Sulman, 1945; Lamond, 1960).

\section{ACKNOWLEDGMENTS}

The NiH-FsH-sl was a gift from the National Institute of Health, Bethesda, U.S.A. Mrs E. Warwick gave most valuable technical assistance.

\section{REFERENGES}

Allorreau, J. J. (1961) Hypophysectomie au début de la gestation et nidation de l'œuf chez la ratte. C. r. hebd. Séanc. Acad. Sci., Paris, 253, 1348.

Alzorteau, J. J. \& Bounours, J. (1965) Hypophysectomie suivant de peu l'ovo implantation chez la ratte; maintien de la gestation grâce à de faibles doses de gonadotropine chorionique humaine ou de gonadotropine sérique de jument gravide. C. r. hebd. Séanc. Acad. Sci., Paris, 260, 306.

Bindon, B. M. \& LAMOND, D. R. (1966a) Description of a mouse colony used for research in reproductive physiology. F. Inst. Anim. Techns, 17, 6.

Bindon, B. M. \& LAMond, D. R. (1966b) Diurnal component in the response by the mouse to gonadotrophin. 7. Reprod. Fert. 12, 249.

Canivenc, R. \& Laffargue, M. (1956) Survie prolongée d'œufs fécondés non implantés, dans l'utérus des rattes castrées et injectées de progestérone. C. r. hebd. Séanc. Acad. Sci., Paris, 242, 2857.

Chambon, Y. (1949) Réalisation du retard de l'implantation par de faibles doses de progestérone chez la ratte. C. r. hebd. Séanc. Acad. Sci., Paris, 143, 756.

Cochrane, R. L. \& Meyer, R. K. (1957) Delayed nidation in the rat induced by progesterone. Endocrinology, 96, 155.

LAMOND, D. R. (1960) Gonadotrophins in rabbit serum after intravenous injection. F. Physiol. Lond. I51, 403.

LAmond, D. R. \& Emmens, C. W. (1959) The effect of hypophysectomy on the mouse uterine response to gonadotrophins. F. Endocr. 18, 251.

MAYER, G. (1963) The experimental control of ovum implantation. In: Techniques in Endocrine Research, p. 213. Eds. P. Eckstein and F. Knowles. Academic Press, New York.

Psychoyos, A. (1963) A study of the hormonal requirements for ovum implantation in the rat, by means of delayed nidation inducing substances (Chlorpromazine, Trifluoperazine). F. Endocr. $27,337$.

Psychoyos, A. (1966) Recent research in egg implantation. In: Egg Implantation, Ciba Foundation Study Group No. 23. Eds. G. E. W. Wolstenholme and M. O'Connor. Churchill, London.

Shelesnyak, M. C. (1960) Nidation of the fertilized ovum. Endeavour, 19, 81.

Shelesnyak, M. G., Kraicer, P. F. \& Zeilmaker, G. H. (1963) Studies on the mechanism of nidation. I. The oestrogen surge of pseudopregnancy and progravidity and its role in the process of decidualization. Acta endocr., Copenh. 42, 225.

YASUKAWA, J. J. \& MEYER, R. K. (1966) Effect of progesterone and oestrone on the pre-implantation and implantation stages of embryo development in the rat. $\mathcal{F}$. Reprod. Fert. 11, 245.

ZeILmakeR, G. H. (1963) Experimental studies on the effect of ovariectomy and hypophysectomy on blastocyst implantation in the rat. Acta endocr., Copenh. 44, 355.

ZoNDEK, B. \& Sulman, F. (1945) The mechanism of action and metabolism of gonadotrophic hormones in the organism. Vitams Horm. 3, 297. 